\title{
Culture Repertoire in Expressive Written Language : Study of Hypothesis of Edward Sapir and Benyamin Lee Whorf
}

\author{
Alfi Syahrin \\ Univerisity of Al-Muslim \\ alfisyahrin745@gmail.com
}

\begin{abstract}
Language, culture, and mind are closely related, each of these extracts reflects one another. The relationship between language, culture and mind of speakers is a basic idea of Sapir and Whorf's theories and hypotheses. Language politeness that is rooted in the splash of the cultural values of the speaking community, including can be seen from the packaging of the information structure as outlined in the sentence of a language. The construction of different clauses grammatically packs different information structures and politeness values. The way of thinking between cultures as outlined in a writing will be different in the way it is delivered. The purpose of this study is to describe culture in expressive writing, is seen from the hypothesis of Edwar Sapir and Benjamin Lee Whorf.
\end{abstract}

Keywords: culture; speech; expressive writing

\section{Introduction}

Language is a medium of communication between humans. Language is needed by humans because human language can find their needs by communicating. As members of the community who are active in everyday life, people are very dependent on the use of language. In other words, where activities occur, there is also a language activity. Chaer (2009: 52), that every language from one community has established a separate world for speakers of that language. So, how many human societies in this world are as many as the number of languages in this world.

The process of producing, processing, organizing, and expressing reality and ideas involving language and mind. The mind functions through language and in language. Only by knowing or knowing something can be captured and understood. Language is human openness to reality. Language and mind are places where reality events occur. Relationship between language and mind can be seen from two sides. First, language is seen as a tool for expressing perceptions, thoughts, and emotions (intumentalism). Second, humans can only perceive, think, and feel because of language (determinism) (Poespoprodjo in Dawud, 2010: 4). A topic that preoccupies experts who study language and thought is the relationship between language and mind, specifically the influence of language on the mind (Nababan, 1992: 156).

Viewed from the Sapir and Whorf hypothesis which generally concerns the role of language in creating a world of reality for humans. According to Sapir and Whorf (Sampson, 1980: 10), the world of human reality is determined solely by language. The thing that makes people understand reality and belongs to the world. Humans cannot live alone in the real world and also in their social life without language. Language becomes the interface between human expression and society and environment. Without language, humans cannot adjust and understand the reality around them. The real world is formed because of the language habits in each group of humans.

Wilhelm von Humboldt who is often referred to as the father of the language of relativity. According to this German philosopher and philosopher, there is a close relationship between society, language, and culture. At the ideal stage, the mixes appear as trinity, one 
community, one language, one culture (Gumperz 1996: 362). Humboldt further explained that the structure of language influences the development of the human mindset, and in every language contained a distinctive worldview. Humans are always faced with reality outside themselves, but reality is present and appears in his mind through the medium of a typical language (Kadarisman, 2009: 34). Language determines a person's thinking patterns in expressing things. Language reflects one's personality and mind.

Judging from Von Humbildt's statement that language is also closely related to culture. Language and culture are two systems inherent in humans. Language as a system that regulates human intraction in society while language as a means of carrying out the intraction. Language is often regarded as a cultural product even an inseparable part of the two things. As a cultural product, language is certainly a forum for cultural aspirations, activities, and community behavior. Cultural disclosures include technology created by the community using the language.

Language as a cultural product contains the values of the speaking community. In the Gayo (Aceh) language there is the phrase "gelah nengon ku toyuh" which means that no matter how high someone's knowledge does not look up, but look down (do not brag). The values contained in it are full of the importance of lowering oneself rather than exalting.

Seeing from this expression, if language and culture have understanding, actors, goals, and styles that are different from other cultures. Therefore, applications in real life differ from one culture to another, so it is clear that each culture is different but its form and movement are manifestations of one of them. Example, in one aspect of language, for example writing (student writing results). In the results of writing we can see that he came from which culture. Because the results of the mindset poured into writing through language reflect culture according to the views of Sapir and Whorf.

\section{Review of Literature}

\subsection{Language and Culture}

According to Sapir, "culture can be defined as what people do and think." When linguists, anthropologists and philosophers examine the relationship between language and culture, they are actually not focused on culture in the broad sense that Sapir uses. Indeed, the study of language and culture in general is focused on ideas, conceptions and beliefs that humans have, but not to cover everything that people do. Because not everything that people do can have an interesting relationship with language. If there were no animals in a community, then people in that community would eat vegetables, but that was not due to the influence of the language. But indeed almost everything that can be done by humans can be poured into language in various ways. When someone's conception of what he does enters into the way we describe what the person is doing, then we can be said to pay attention to the relationship between the language of the person and the activities he does (Cooper, 1979: 146).

The relationship between language, culture, and mind is reflected in the linguistic theory of relativity and Sapir-Whorf's hypothesis. According to Wardhaugh (1988: 212), the existing opinions about the relationship between language and culture that have survived for a long time are: (i) the structure of language determines the ways in which the speakers of the language perceive their world; (ii) community culture is reflected in the language they use, 
because they have everything and do it in a certain way that reflects what they value and what they do. In this view, cultural instruments do not determine the structure of language, but these devices clearly influence how language is used and may determine why these cultural beads are a way of speaking; and (iii) there is little or no relationship between language and culture. The statement that the structure of language influences how the speaker views the world, actually was introduced by Humbolt in the 19th century, but now the statement is known as the hypothesis of Sapir-Whorf or Whorfian hypothesis.

Sapir and Worf say that no two languages have similarities to be considered as the same social reality. Sapir and Worf describe two hypotheses regarding the relationship between language and mind. The first hypothesis is lingusitic relativity hypothesis which states that differences in the structure of language are generally parallel to non-language cognitive differences. Language differences cause differences in the minds of people who use the language. The second hypothesis is linguistics determinism which states that the structure of language influences the way individuals perceive and reason the perceptual world. In other words, the structure of human cognition is determined by the categories and structures that already exist in language.

The influence of language on the mind can occur through habituation and through formal aspects of language, such as grammar and lexicon. Whorf said "grammatical and lexical resources of individual languages, heavily constrain the conceptual representations available to their speakers". Grammar and lexicon in a language determine the conceptual representation that exists in the user's language. Besides habituation and formal aspects of language, one of the dominant aspects in the concept of Whorf and Sapir is the problem of language influencing categorization in human perception which will be the premise in thinking (Widhiarso, 2005: 2).

Language for Whorf guides social reality. Although language is usually not in demand by social scientists, language strongly conditions individual thoughts about a problem and a social process. Individuals do not live in an objective world, not only in the world of social activities as they are commonly understood, but are very much determined by certain languages which are the medium of statement for their society. There are no two languages that are equal enough to represent the same reality. The world of various peoples' lives is valued by Whorf as the same world but with different characteristics. In short, it can be concluded that human views about the world are shaped by language so that because language is different then the view of the world is different. Selectively, individuals filter sensory as they are programmed by the language they use. That way, people who use different languages have sensory differences too (Rachmat, 1999).

The reality of language, both as text and context, is one system in culture. Language and culture are reciprocal. The study of interdisciplinary fields of language and culture is suspected as cultural linguistics. The main concern of linguistic culture is not how people say an objective reality, but how people say something they think. Influential thoughts and how to determine languages that are formulated in a cultural meaning behind the use of language. Most human behavior is surrounded by language, so language becomes an inseparable part of culture. For example, the reality of ceremonies, songs, laws are actions, events and language events. Anyone who enters and understands a culture must master the language because only through language can a person participate and experience a culture for themselves. 
Sapir and Whorf stated that the linguistic system behind each language is not merely a reproductive instrument for voicing ideas, but that linguistic system forms ideas and the system is a program and guide for one's mental activity, for analysis of its impression, and for treasury exchange mental synthesis of its contents (Whorf in Dawud, 2010:5). Some aspects of the discussion that affect the mind need to be identified further, for example the identification of aspects of language that influence the reasoning of spatial fields and aspects of language that influence reasoning to other thoughts.

\section{Discussion}

\subsection{Expressive Written Language in Culture}

Speech is a utterance from a speaker to a partner while communicating. Speech in pragmatics is defined as a product of a verbal act (not a verbal act itself) (Leech, 1993: 20). Meanwhile Austin states that all speech is a form of action and not just something about the world of speech or speech (speech act) is a function of language as a means of action, all speeches uttered by speakers actually contain certain communicative functions. Based on this opinion it can be said that saying something can be referred to as an activity or action. This is possible because in each speech has a certain purpose that affects others.

Of the several classes of speech acts, one of them is expressive speech. Expressive speech is part of illocutionary speech acts. Expressive speech is a speech act that is intended by the speaker so that the utterance can be interpreted as an evaluation of the thing mentioned in the speech and has several functions in it. Expressive speech has several functions which consist of criticizing / insinuating, complaining, blaming, congratulating, thanking, flattering, and apologizing.

Furthermore, this speech act also serves to express the feelings and attitudes of speakers to the circumstances implied in ilokusi for example: thanking, congratulating, forgiving, criticizing, praising, expressing condolences, criticizing, complaining, blaming, regret and so on. This illocutionary speech tends to be fun, because it is intrinsically illocutionary polite, except expressive illocutionary criticism, regret and blame.

Expressive speech or expressive speech acts are speech acts intended by the speaker so that the speech can be interpreted as an evaluation of the things mentioned in the speech. This form of speech has the function of expressing or expressing the psychological attitudes of the speaker to the other person. As for some expressive speech functions contained in a utterance delivered by the speaker to the opponent, which can function to congratulate, thank you, criticize, complain, blame, flatter / praise, apologize, and insinuate.

Examples of expressive utterances in congratulations. Expressive expressions of congratulations are speech acts that occur because of several factors, namely the speaker gets something special, the speaker gives a special speech to the opponent, or as a greeting or greeting to the time so that the opponent says congratulations to the speaker as an expression of happiness. The following is one example of expressive utterances of congratulations.

"Good evening and welcome to this beloved city, a city full of fresh air" ... "Thank you for the welcome, I am happy to be here".

The sentence contained a conversation in the form of expressive greeting between speakers and opponents of speech. Speeches "good night and welcome to this beloved city, a 
city full of fresh air" delivered by speakers to opponents said. The speech meant to give a good evening and welcome to the invited guests who served as opening greetings.

The word "safe" is actually a greeting so that hopefully the person concerned is in good condition, healthy, and prosperous. For example, like the saying "good night" to the data that means hopefully surviving at night and "welcome" which means hopefully surviving his arrival.

Every culture to say or how to pronounce it is definitely different. Different cultures must also be different from the way the speakers welcome their opponents. Therefore, culture reflects a person's culture. In an association consisting of various tribes, for example Gayo (Aceh), Makassar, Riau, Padang, Ambon, Manado, Pontianak, Solo, Jember, Malang, Lombok with different cultural backgrounds. Every congratulatory spoken must be different. Culture is a way of life that develops and is shared by a group of people and is inherited from generation to generation. Culture is formed from many complex elements, including religious and political systems, customs, languages, tools, clothing, buildings, and works of art. Language, as well as culture, is an inseparable part of human beings so that many people tend to think of it as being genetically inherited. When someone tries to communicate with people who are culturally different and adjust their differences, it proves that the culture is learned. Culture is a comprehensive lifestyle. culture is complex, abstract and broad.

\section{Conclusion}

Language and culture are inseparable sequences. Language is a product and process of its role as part of culture. Language behaves in ways of thinking and how to organize experiences in a culture. Like the Sapir and Whorf hypotheses which are hypotheses which are famous for the relationship of mind and language. The Sapir and whorf hypotheses commonly known as the language relativity theory and cultural determination there are stated if differences in thinking are caused by differences in language, if made to look into Indonesian especially and some languages in Indonesia there are indeed some things that can be made into references or reference to this hypothesis.

However, with the Sapir and Whorf hypothesis, the Indonesian people in particular as well as those who use languages in Indonesia can be used as valuable lessons, because departing from this hypothesis that language is seen to have a major influence on culture (culture) which accommodates because language determines the way of thinking of individuals . Language has a great influence on culture and determines the forms of culture.

\section{References}

Austin, J. L. 1962. The Meaning of a Word. New York: Oxford University Press. Cooper, David E. 1979. Philosophy and the Nature of Language. London: Longman. Chaer, Abdul. 2009. Psikolinguistik: Kajian Teoretik. Jakarta: Rineka Cipta.

Dawud. 2010. Pembelajaran Berargumentasi Tulis Bahasa Indonesia. Makalah pidato pengukuhan guru besar. Tidak diterbitkan. Malang: Universitas Negeri Malang. 
Gumperz, Jhon J. \& Stephen Levinson. 1996. Rethinking Linguistic Relativity. Cambridge University Press.

Kadarisman, A. Effendi. 2009. Mengurai Bahasa Menyibak Budaya. Malang: UM Press.

Nababan, Sri Utami. 1992. Psikolinguistik Suatu Pengantar. Jakarta: Gramedia Pustaka Utama.

Rakhmat, J. 1999. Psikologi Komunikasi. Bandung: Rosdakarya.

Sampson, Geoffrey. 1980. Schools Of Linguistics. Standford: Standford University Press.

Wardhaugh, Ronald. 1988. An Introduction to Sociolinguistics. Oxford: Basil Blackwell.

Widhiarso, Wahyu. 2005. Pengaruh Bahasa terhadap Pikiran: Kajian Hipotesis Benyamin Whorf dan Edwar Sapir. (artikel). Jogjakarta: UGM. 